\title{
Brand loyalty as mediator of brand image-repurchase intention relationship of premium-priced, high-tech product in Indonesia
}

\author{
Hetty Karunia Tunjungsari* \\ Faculty of Economics and Business Universitas Tarumanagara, Jl. Tanjung Duren Utara \\ No. 1 Grogol, Jakarta Barat, 11410, Indonesia \\ hetty@fe.untar.ac.id \\ Jhanghiz Syahrivar \\ Department of Marketing, Corvinus University of Budapest, Hungary \\ School of Business, President University, Jl. Ki Hajar Dewantara, North Cikarang, \\ West Java, 17530, Indonesia \\ jhanghiz@president.ac.id \\ Chairy Chairy \\ School of Business, President University, Jl. Ki Hajar Dewantara, North Cikarang, \\ West Java, 17530, Indonesia \\ chairy@ president.ac.id \\ *Penulis Korespondensi
}

Submitted: Aug 08, 2020; Reviewed: Aug 09, 2020; Accepted: Sept 17, 2020

\begin{abstract}
This research aims to examine whether there is a mediating role of brand loyalty in the relationship between brand image and repurchase intention of premium-priced, high-tech product in Indonesia. We chose Apple brand in this research through a preliminary study involving 50 respondents. From the self-administered survey, we concluded Apple were perceived as the premiumpriced, high-tech product. After the preliminary study, we collected 210 users of Apple products to participate in our research. Hypotheses testing were done using linear regression in IBM SPSS Statistics version 24 and Hayes' Macro Process version 3.3 model 4. Research findings show that all hypotheses were supported by the data, brand image significantly and positively influences repurchase intention and brand loyalty mediates the influence of brand image on repurchase intention. Research implications are discussed further in this article.
\end{abstract}

Keywords: brand image; brand loyalty; high-tech product; premium price; repurchase intention

Abstrak: Penelitian ini bertujuan untuk menguji apakah terdapat peran mediasi loyalitas merek dalam hubungan antara citra merek dan niat membeli kembali produk berteknologi tinggi berharga premium di Indonesia. Kami memilih merek Apple dalam penelitian ini melalui studi pendahuluan yang melibatkan 50 orang responden. Dari survei yang dilakukan, kami menyimpulkan bahwa Apple dianggap sebagai produk berteknologi tinggi dengan harga premium. Setelah studi pendahuluan, kami mengumpulkan 210 orang pengguna produk Apple untuk berpartisipasi dalam penelitian kami. Pengujian hipotesis dilakukan dengan menggunakan regresi linier pada IBM SPSS Statistics versi 24 dan Hayes Macro Process versi 3.3 model 4. Hasil penelitian menunjukkan bahwa semua hipotesa didukung oleh data, citra merek berpengaruh secara signifikan dan positif terhadap niat beli kembali dan loyalitas merek memediasi pengaruh citra merek terhadap niat membeli kembali. Implikasi penelitian juga akan dibahas lebih lanjut dalam artikel ini. 
Jurnal Manajemen Maranatha ø Vol. 20 Nomor 1, November (2020)

Kata kunci: citra merek; harga premium; loyalitas merek; pembelian kembali; produk berteknologi tinggi

\section{INTRODUCTION}

The market of premium-priced, high-tech products in the world is growing rapidly in the recent years (Jung, Baek, \& Lee, 2012; Li, Li, \& Kambele, 2012). For instance, in Indonesia, this can be seen from the increasing variety of premium-priced, high-tech products in various product categories that can be easily found in the market. Premium-priced, high-tech products with global label brands, such as Apple, Samsung, Nikon, JBL, Electrolux, Garmin, etc., can be easily purchased by high-end consumers in Indonesia.

Apple, Inc. is one of the electronics companies that apply premium pricing strategy to their hightech products (Nielson, 2014). Nick Zarb, technology expert and Senior Director at Simon-Kucher \& Partners, explains there is clearly a segment of customers that are willing to pay whatever it takes to access the latest and greatest iPhones. Indeed, Apple's brand continues to be on the list of the 100 most powerful global brands (Badenhausen, 2019). Prajapati (2020) mentioned that Apple represents the shiny future of the tech industry which make its products a head-turner because everyone believes that Apple is the new future.

Knerl (2012) said that many consumers did not mind with the premium price on almost all Apple's new products since the Apple brand had a significant value for them and it instilled the feeling of security. This can be interpreted that most users of Apple products have a tendency to repurchase Apple products as soon the new products are launched in the market. Repurchase by Apple consumers signified a good experience felt by users of Apple brand products. Moreover, repurchase can be an indicator of success certain products or brands (Razak, Themba, \& Sjahruddin, 2019).

As Apple Inc.'s flagship product, iPhone contributed more than 50\% of the total sales of Apple products. But as quoted in http://cnbcindonesia.com, the third quarter financial report for the 2019 fiscal year showed that for the first time in 7 years iPhone global sales were below $48 \%$. Even in markets that usually have high growth, such as India, Indonesia, Korea and Vietnam, there is no positive increase over the previous year (http://international.kontan.com). Despite the decline in sales, Hal Eddins, an analyst at Capital Investment Counsel, said that when people wanted to splurge on cellphones, they did it on Apple products. Athur (2015) stated that unlike other competitors, such as Samsung, Sony, HTC, and LG, Apple had consistently been able to convince loyal consumers to buy the latest models of Apple products as well as making users of competing brands switch to Apple brand. Anselmsson, Bondesson, \& Johansson (2014) argued that a brand could apply a certain positioning strategy in order to motivate a certain market segment pay more for a product or service. A brand is said to be premium when consumers have a high desire to pay for a product based on their brand compared to competing brands in similar product category (Aaker \& Biel, 2013). While Cheng \& Cheng (2013) also found that premium pricing had a significant positive effect on purchase intention.

The discussion in this article will begin with the presentation of the concepts of brand image, brand loyalty, and repurchase intention in the context of premium-priced, high-tech products. Methodology section will discuss on how researchers selected the sample and conducted data analysis and hypothesis testing. The final section of this paper will discuss the results of this research as well as its implications.

According to Wijaya (2013), almost all products had brands and almost all companies struggled to develop and maintain the brand reputation of the company's products. One important element in developing a brand is brand image. Keller (2013) defined brand image is brand information imprinted in consumers' minds and memories in the form of associations or beliefs. Meanwhile, Nandan (2005) defined brand image as a concept carried out by consumers based on reasons and emotions that are subjective and perceptual, so that consumers' perception of a brand became more important than the actual performance of the brand. Brand image is also defined as a collection of perceptions and feelings of consumers formed by their experiences of a particular product or brand by involving cognitive, sensory, and emotional aspects (Aaker, 2008). 
When a brand engages consumers in cognitive, sensory, and emotional levels, the brand develops into a love mark that is formed by three factors, namely mystery, sensuality, and intimacy (Roberts, 2004). Moreover, when the brand has high brand awareness, perceived quality, and perceived prestige value, it can create price premium (Bougenvile \& Ruswanti, 2017; Gómez, Martín-Consuegra, Díaz, $\&$ Molina, 2018). At this point, consumers are more likely to purchase certain brands and are even willing to pay a premium price because its benefits meet their needs (Kadirov, 2015).

A good attitude formed by positive experiences in using a product can form brand loyalty, which is divided into attitudinal and behavioral perspectives (Dick \& Basu, 1994). In an attitudinal perspective, brand loyalty can be aroused when consumers have trust and a good attitude towards a brand (Keller, 2013). Attitudinal brand loyalty reflects a consumer's deep commitment towards a chosen brand by liking the brand continuously (Aaker, 2008). In this concept, consumer loyalty to a brand is formed in 3 stages, cognitive, affective, and conative. The cognitive stage is the stage where consumers buy a brand through logical considerations, such as quality, price, and the need or problem that underlies the purchase. When consumers buy products because of irrational considerations, such as feelings or emotional responses, consumers are at the affective stage (Back \& Parks, 2003). In the conative stage, consumers actively act on the decision whether to buy or not buy a product.

In the behavioral perspective, Aaker (2008) argued that brand loyalty must be measured based on the number of brands paid, the percentage of purchases, and the intention to purchase in the future. When a customer is loyal, they will buy the brand, even if the company raises its price or changes its features. Furthermore, Aaker (2008) also identified 5 levels of brand loyalty, ranging from consumers who are not loyal to the brand (switchers), consumers who tend to buy brands and do not look for other alternative brands (habitual buyers), consumers who do not want to switch to brand substitution, which is caused price changes and performance risk (satisfied buyers), and finally buyers who love the brand because of an emotional connection, who would form friendships with the brand in the long run (committed buyers).

In everyday life, we can find the fact that some consumers who are satisfied with their previous purchase experience with regards to certain brands will generally have the desire to make repeat purchases in the future. Consumers who have a strong purchase intention have a higher probability of making repeat purchase (Goh, Jiang, Hak, \& Tee, 2016; Hellier, Geursen, Carr, \& Rickard, 2003). Marketers consider that consumer repurchase intention is more important because it indicates a continuing purchase in the future (Kuo, Hu, \& Yang, 2013; Zeithaml, 2000). Bayraktar, Tatoglu, Turkyilmaz, Delen, \& Zaim (2012) define repurchase intention as an individual's assessment whether to make a repeat purchase on the product he or she previously bought and used, a decision that also includes future activity with a service provider.

The higher the consumer's perception on brand image, the higher the consumer's intention to repurchase the brand in the future (Chen \& Hsieh, 2011). In other words, a brand that has a positive image in the minds of consumers will have a greater chance of being repurchased in the future than a brand with a lower image. The condition where the consumer repurchases a brand indicates that the consumer is at the loyal stage. A research by Yin-Tsuo, Kuo-Wei, \& Wen-Yuan (2011) reinforces this opinion that consumers' positive perception on the image of a brand has a significant influence on brand loyalty, where brand loyalty is closely related to the repurchase situation.

This research will examine the effect of brand image and brand loyalty on the repurchase intention of Apple products. Brand loyalty is hypothesized as a mediating variable that has a role in the relationship between brand image and repurchase intention. Figure 1 depicts a model proposed in our research.

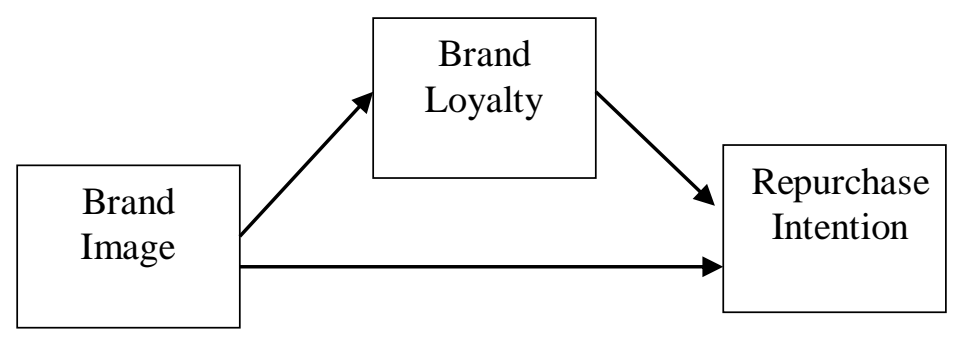

Figure 1. Research model

Source: Processed research data 
The hypotheses proposed in this research are as follows:

Hypothesis 1: there is a positive relationship between brand image and repurchase intention.

Hypothesis 2: there is a positive relationship between brand image and brand loyalty.

Hypothesis 3: there is a positive relationship between brand loyalty and repurchase intention.

Hypothesis 4: there is a mediating role of brand loyalty in the relationship between brand image and repurchase intention.

Seeing the market development of Apple product in Indonesia as a premium-priced, high-tech product, as well as the opinion that the majority buyers of Apple products are its existing customers, researchers are interested in examining the effect of brand image and brand loyalty on repurchase intentions of Apple products in Indonesia.

\section{METHOD}

The sample of this research were 210 users of Apple products in various cities in Indonesia obtained through purposive sampling technique. We distributed questionnaires to colleagues who were Apple users and asked for their recommendations regarding other Apple users within their networks who would fill in the questionnaire. This technique is intended to get a high and fast response rate (Ness \& Rooney, 2013; Cho, 2011). Respondents involved in this research must satisfy certain criteria, such as being Apple users and that they had at least one Apple's product, such as MacBooks, iPhones, iPads, iPods, and iMacs.

There were 3 variables being measured in this research, namely brand image, brand loyalty, and repurchase intention. This study adapted the scale of the brand image developed by Cho (2011). As for the scale of brand loyalty and repurchase intention, we adapted the scales developed by Keller (2013) and Kabiraj \& Shanmugan (2011). The items were measured using a 5-point Likert scale, where 1 indicates strongly disagree and 5 indicates strongly agree. Table 1 presents the instruments employed in this research. The methodology must be clearly stated and described in sufficient detail or with sufficient references. The author shall explain the research question, describe the research framework, and the methods applied in detail. It should be furthermore highlighted why the research question is relevant to theory and practice, and why the chosen method(s) are suited for the problem.

Table 1. Research instruments

\begin{tabular}{ll}
\hline Brand image \\
\hline Mystery & Apple brand adds to the experience of my life. \\
& Apple brand awakens good memories for me. \\
Apple brand captures a sense of my life. \\
Sensuality \\
The design of Apple brand is really well done. \\
The packaging of Apple brand is as pleasing as the product. \\
Apple brand has a beautiful color scheme. \\
Apple brand has incredible displays. \\
I feel connected to Apple brand. \\
I feel happy when I use Apple brand. \\
I have fun with Apple brand. \\
I really enjoy using Apple brand. \\
\hline Brand loyalty \\
I feel Apple is a brand of electronic products/ gadgets that I need. \\
As long as I am able, I will continue to buy Apple brand. \\
Apple is a brand of electronic products/ gadgets that I always choose. \\
I will put my best effort so that I can remain using Apple brand. \\
I will be disappointed if one day Apple brand no longer exists. \\
\hline Repurchase intention \\
I intend to repurchase Apple products. \\
I hope I can buy Apple products again in the future. \\
I will not buy Apple products anymore.* \\
I hope I can buy the latest products from Apple. \\
I feel loyal to Apple.
\end{tabular}

*reversed item

Source: Processed research data 


\section{RESULT AND DISCUSSION}

\subsection{Results of validity and reliability test}

Based on the data obtained, 210 valid samples could be further processed. The sample consisted of 115 women $(54,5 \%)$ and 95 men $(45,2 \%)$. The number of respondents who worked was 107 people $(51 \%)$, while respondents who did not work were 103 people (49\%). Validity testing is done through confirmatory factor analysis in IBM SPSS Software. The indicator of each construct that has a significant factor loading shows that the indicator is a unit of measuring the same construct and can predict the constructs that should be predicted (Hair, Babin, \& Anderson, 2018). Furthermore, reliability test is also done using reliability analysis in IBM SPSS Software. The results of validity and reliability tests showed that all instrument items were valid and reliable because all factors were above 0,4 and Cronbach's Alpha values were above 0,6 as can be seen in Table 2 and Table 3 .

Table 2. Validity test report

\begin{tabular}{|c|c|c|c|c|}
\hline Construct & Item & Factor loading & & \\
\hline \multirow{9}{*}{ Brand image } & M1 & 0,556 & & \\
\hline & M2 & 0,581 & & \\
\hline & M3 & 0,706 & & \\
\hline & S1 & 0,465 & & \\
\hline & S2 & 0,687 & & \\
\hline & S3 & 0,686 & & \\
\hline & I1 & 0,668 & & \\
\hline & $\mathrm{I} 2$ & 0,755 & & \\
\hline & I3 & 0,528 & & \\
\hline \multirow{3}{*}{$\begin{array}{l}\text { Repurchase } \\
\text { intention }\end{array}$} & $\mathrm{R} 1$ & & 0,436 & \\
\hline & R2 & & 0,639 & \\
\hline & R3 & & 0,797 & \\
\hline \multirow[t]{3}{*}{ Brand loyalty } & L1 & & & 0,814 \\
\hline & L2 & & & 0,801 \\
\hline & L3 & & & 0,756 \\
\hline
\end{tabular}

Source: Processed research data

Table 3. Reliability statistic (cronbach's alpha)

\begin{tabular}{lc}
\hline Variable & $\begin{array}{c}\text { Cronbach's } \\
\text { alpha } \geq 0,6\end{array}$ \\
\hline Brand image &, 905 \\
Repurchase intention &, 750 \\
Brand loyalty &, 896 \\
\hline
\end{tabular}

Source: Processed research data

\subsection{Results of pilot study}

This research began with a pilot study to get a scientific basis that Apple is a brand perceived as a premium-priced, high-tech product by consumers in Indonesia. The pilot study was conducted by distributing questionnaires to 50 respondents with a number of open questions such as "Name three brands of gadgets that you have had in the past 5 years", "Name five brands of gadgets that you think have premium prices", "Name three gadgets that are important for you to have now and beyond", and "Name the most prestigious gadget brands".

The results of the pilot study showed that Samsung was perceived to be the gadget brand most owned $(50 \%)$, followed by Apple (30\%), Oppo (10\%), and others (10\%). All respondents ranked Apple as the number one gadget brand with a premium price. Mobile phone was a gadget that need to be owned today and beyond (80\%), followed by laptops (60\%) and tablets (30\%). As many as $90 \%$ of respondents also perceived that Apple as the most prestigious brand for gadgets. Apple has positioned itself as a high-end or luxury brand. The brand is perceived as worth the expense. Based on the results of this pilot study, we have a strong evidence that Apple is a brand perceived as a premium-priced, high-tech product in Indonesia. Therefore, Apple is the right subject in this study. 


\subsection{Hyphotheses testing}

The research hypotheses testing that was carried out after the validity and reliability tests. To test the mediation model proposed in this study, we used a statistical test tool IBM SPSS version 24 with a macro Process Hayes version 3.3 model 4. Figure 2 shows a simple mediation research model in the form of a statistical diagram.

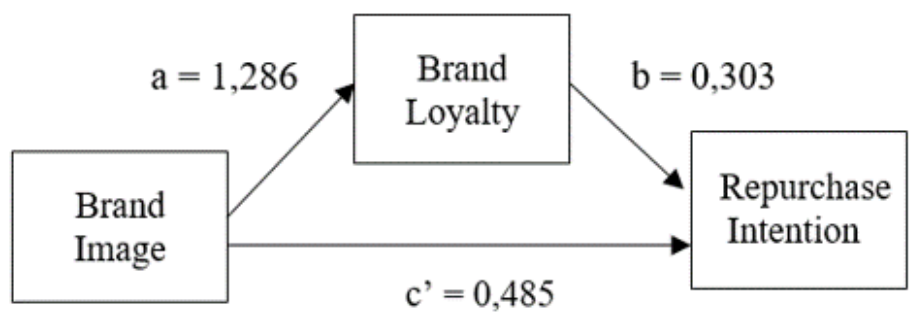

Figure 2. Statistical diagram

Source: Processed research data

Statistically, hypotheses 1 through 4 in this study were proven to be supported by data, where with 95\% bootstrap confidence intervals all values of LLCI and ULCI are between 0 and 1 . In Table 3, we can see a summary of the results of simple mediation testing using Hayes Process version 3.3. From these results it can be seen that the values of $a=1,286, b=0,303$, and $c^{\prime}=0,4851$ and the regression equation can be arranged in the following form:

$\mathrm{iM}=-1,329+1,286 \mathrm{X}$

$\mathrm{iY}=0,9756+0,4581 \mathrm{X}+0,303 \mathrm{M}$

Indirect effect (ab) has a value of 0,3897, which means a difference in perception of brand image by 1 unit between two consumers will result in a difference in repurchase intentions by 0,3897 . This direct effect is statistically not equal to 0 as shown by $95 \%$ bootstrap confidence interval which is entirely above the value of 0 (LLCI and ULCI values are between 0,2595 and 0,319).

The direct effect of brand image ( $\left.c^{\prime}\right)$ is 0,4851 which is the difference in repurchase intentions of two consumers with the perception of the same brand image but with a difference in one unit of brand loyalty. Coefficient $c^{\prime}$ is positive which means that if someone has a more positive perception towards brand image but has the same level of brand loyalty then he will have a higher repurchase intention by 0,4851 units. Statistically, the direct effect is not equal to 0 as shown by $95 \%$ bootstrap confidence interval which is entirely above the value of 0 (LLCI and ULCI values are between 0,3233 and $0,6469)$.

The total effect of brand image on repurchase intention is obtained from the sum of direct effects and indirect effects or by observing the regression between repurchase intention and brand image ( $\mathrm{c}=$ $\left.c^{\prime}+a b=0,4851+0,3897=0,8748\right)$. Two consumers who have a difference of one unit in the perception of brand image are estimated to have a difference in repurchase intention by 0,8748 . The effects produced are statistically not equal to 0 where $\mathrm{t}(210)=15,1981, p=0,000$ or between 0,7613 and 0,9882 with $95 \%$ bootstrap confidence interval.

Table 3. Model coefficients

Antecedent

$\mathrm{X}$ (Brand image)

a

M (Brand loyalty)

$i M$

Constant

\begin{tabular}{|c|c|c|c|c|c|c|}
\hline \multicolumn{7}{|c|}{ Consequent } \\
\hline \multicolumn{3}{|c|}{ M (Brand loyalty) } & \multicolumn{4}{|c|}{ Y (Repurchase intention) } \\
\hline Coeff. & SE & $p$ & & Coeff. & SE & $p$ \\
\hline \multirow{2}{*}{$\begin{array}{l}1,286 \\
<0,001\end{array}$} & 0,0753 & & $\mathrm{c}^{\prime}$ & 0,4581 & 0,0821 & 0,000 \\
\hline & - & & $\mathrm{b}$ & 0,3030 & 0,0487 & $<0,001$ \\
\hline $\begin{array}{r}-1,329 \\
<0001\end{array}$ & 0,3180 & & $i Y$ & 0,9756 & 0,2328 & $<0,001$ \\
\hline \multicolumn{3}{|c|}{$\begin{array}{l}\mathrm{R}^{2}=0,5835 \\
\mathrm{~F}(1,210)=291,4067, p<0,01\end{array}$} & & \multicolumn{3}{|c|}{$\begin{array}{l}\mathrm{R}^{2}=0,6007 \\
\mathrm{~F}(2,210)=155,7034, p<0,01\end{array}$} \\
\hline
\end{tabular}

Source: Processed research data 
The result shows positive relationship between brand image and brand loyalty that corroborates Cho (2011) who shows a strong relationship between positive brand image and brand loyalty. This research proves that a good brand image will also affect brand loyalty to consumer which also support the research of Habib \& Aslam (2014) who found that a company with a positive image of its product or service can increase their competitive advantages.

As in the research of Habib \& Aslam (2014), the results of this study show that there is a positive relationship between brand loyalty and repurchase intention. Consumer loyalty is a deep commitment to buy or repurchase selected products consistently in the future, which causes repetition of purchases of the same brand, even though there are situations or other marketing efforts that have the potential to cause changes in consumer behavior. This research also supported by Schultz (2005) which explained that loyal consumer tends to talk about the brand they uses and recommend to their relatives.

This research also proves the mediating role of brand loyalty in the relationship between brand image and repurchase intention of Apple products. The mediation produced in this research model is partial because both direct and indirect testing obtained statistical values which are not equal to 0 . Loyal consumers have confidence and a sense of love for brand characteristics, such as affection, passion, and connections (Kabiraj \& Shanmugan, 2011; Thomson, Debora, \& Park, 2005; Kahney, 2012). This can be interpreted that Apple users in this study build their loyalty through Apple's positive brand image. The results of this research also illustrate that Apple users trust the Apple brand. As stated by Kahney (2012), Apple is an archetypal emotional brand that not only has a close relationship with its consumers but is also loved by them. This is indicated by the presence of direct and indirect brand image effects on repurchase intention of Apple products.

\section{CONCLUSION}

In line with the development of premium-priced, high-tech product market in the world in recent years, various kinds of premium-priced, high-tech products in various product categories can be easily found in the Indonesian market. This research investigates the effect of brand image on repurchase intention of Apple products in Indonesia with band loyalty as a mediator. The results showed a significant effect of brand image on repurchase intention.

The results of this research also show the role of brand loyalty as a mediator in the relationship between brand image and repurchase intention. The results are expected to encourage premium-priced high-tech product marketers, especially marketers of Apple products in Indonesia, to always pay attention to brand image as an antecedent of repurchase intention. Apple needs to constantly improves its devices based on what customers want as well as the need to continue to improve brand loyalty. Apple needs to maintain the ability to make customers happy which in the end ensures that customers will stay loyal and continue to purchase from the company, while bringing in new customers in the process.

To get a good brand image for consumers, companies must be able to establish good relationships with consumers. In every new product launch, Apple always features the CEO to present its product. With this way, Apple can make its users feel valued because it creates a sense of pride which make the product that will be used by these consumers has an influence or direct intervention by an owner or senior people at Apple. To encourage customer loyalty, companies can provide special facilities for existing users, such as pre-order services at special prices, as well as convenient payment facilities. The installment payment method can be applied to premium price products by considering that the price offered is high value, so it does not burden consumers. In addition, companies must always carry out continuous innovation in accordance with consumer needs.

Future studies need to investigate the relationship between brand image, brand loyalty, and repurchase intention with other variables such as personal characteristics and consumer's buying motives. Brands give consumers the possibility of enhancing their social identity by wearing branded clothes or discussing the brand and its products online (McGowan, Shiu, \& Hassan, 2017). Consumers' buying motive of premium-priced, high-tech products in order to enhance social identity might play as moderating as well as mediating variable in the brand image-brand loyalty-repurchase intention relationship. 


\section{REFERENCE}

Aaker, D. A. (2008). Managing brand equity: Capitalizing on the value of a brandname. New York: Free Press.

Aaker, D. A., \& Biel, A. L. (2013). Brand equity \& advertising: Advertising's role in building strong brands. New York: Psychology Press.

Athur, C. (2015). Why is Apple customers' appetite for its products intsatiable? Retrieved from https://www.theguardian.com/technology/2015/sep/04/apple-customers-appetite-productsinsatiable.

Anselmsson, J., Bondesson, N. V., \& Johansson, U. (2014). Brand image and customers' willingness to pay a price premium for food brands. Journal of Product \& Brand Management, 23(2), 90-102. doi: 10.1108/JPBM-10-2013-0414.

Back, K. J., \& Parks, S. C. (2003). A brand loyalty model involving cognitive, affective, and conative brand loyalty and customer satisfaction. Journal of Hospitality \& Tourism Research, 27(4), 419435. Retrieved from https://doi.org/10.1177/10963480030274003.

Badenhausen, K. (2019). The world's most valuable brands 2019: Apple on top at 206 billion. Forbes. Retrieved from https://www.forbes.com/sites/kurtbadenhausen/2019/05/22/the-worldsmost-valuable-brands-2019-apple-on-top-at-206-billion/\#7c9c7e8337c2.

Bayraktar, E., Tatoglu, E., Turkyilmaz, A., Delen, D., \& Zaim, S. (2012). Measuring the efficiency of customer satisfaction and loyalty for mobile phone brands with DEA. Expert Systems with Applications, 39(1), 99-106. doi 10.1016/j.eswa.2011.06.041.

Bougenvile, A., \& Ruswanti, E. (2017) Brand equity on purchase intention consumers' willingness to pay premium price juice. Journal of Economics and Finance, 8(1), 12-18. doi: 10.9790/59330801031218.

Chen, H., \& Hsieh, T. (2011). A Study of antecedents of customer repurchase behaviors in chain store supermarket. The Journal of International Management Studies, 6(3). Retrieved from https://pdfs.semanticscholar.org/b0dc/809518150772d92eed2ff290bd94ae02de1d.pdf?_ga=2.15261 2473.1583528269.1599026611-693271446.1599026611.

Cheng, H. P., \& Cheng, H. T. (2013). The influence of brand and price on purchase intention of mobile phone in the case of Taiwan college students. Applied Mechanics and Materials, 411-414, 2326-2329. doi: 10.4028/www.scientific.net/AMM.411-414.2326.

Cho, E. (2011). Development of a brand image scale and the impact of lovemarks on brand equity (Doctoral dissertation). Retrieved from http://lib.dr.iastate.edu/cgi/viewcontent.cgi?article=2951\&context=etd.

Dick, A. S., \& Basu, K. (1994). Customer loyalty: Toward an integrated conceptual framework. Journal of The Academy of Marketing Science, 22(2), 99-113. Retrieved from https://doi.org/10.1177/0092070394222001.

Goh, S. K., Jiang, N., Hak, M. F. A., \& Tee, P. L. (2016). Determinants of smartphone repeat purchase intention among Malaysians: A moderation role of social influence and a mediating effect of consumer satisfaction. International Review of Management and Marketing, 6(4), 993-1004. Retrieved from https://search.proquest.com/openview/d6a6905420203bba32de5354595ccc43/ 1 ?pq-origsite $=$ gscholar\&cbl $=816339$.

Gómez, M., Martín-Consuegra, D., Díaz, E., \& Molina, A. (2018) Determinants and outcomes of price premium and loyalty: A food case study. Journal of Consumer Behavior, 17(1), 64-74. Retrieved from https://doi.org/10.1002/cb.1692.

Habib, S., \& Aslam, S. (2014). Influence to brand loyalty on consumer repurchase intentions of cocacola. European Journal of Business and Management, 14(6), 168-175. Retrieved from https://www.iiste.org/Journals/index.php/EJBM/article/view/13343/13205.

Hair, J. F., Babin, B. J., \& Anderson, R. E. (2018) Multivariate data analysis. Boston: Cengage Learning EMEA.

Hellier, P. K., Geursen, G. M., Carr, R. A., \& Rickard, J. A. (2003). Customer repurchase intention: A general structural equation model. European Journal of Marketing, 37(11/12), 1762-1800. doi: $10.1108 / 03090560310495456$.

Hutauruk, D. M. (2019, April 5). Penjualan iPhone diproyeksi merosot jauh melampaui penurunan industry. Kontan.co.id. Diakses dari https://internasional.kontan.co.id/news/penjualan-iphonediproyeksi-merosot-jauh-melampaui-penurunan-industri.

Jung, E., Baek, C., \& Lee, J. (2012). Product survival analysis for the App Store. Marketing Letter, 23(4), 929-941. doi:10.1007/s11002-012-9207-0.

Kabiraj, S., \& Shanmugan, J. (2011). Development of a conceptual framework for brand loyalty: A Euro-Mediterranean perspective. Journal of Brand Management, 18, 285-299. Retrieved from http://dx.doi.org/10.1057/bm.2010.42.

Kadirov, D. (2015). Private labels ain't bona fide! Perceived authenticity and willingness to pay a price premium fornational brands over private labels. Journal of Marketing Management, 31(1718), 1773-1798. Retrieved from https://doi.org/10.1080/0267257X.2015.1031265.

Kahney, L. (2012). Apple: It's all about the brand. Retrieved from 
https://www.wired.com/2002/12/apple-its-all-about-the-brand/.

Keller, K. L. (2013), Strategic brand management: Building, measuring, and managing brand equity, 4th ed. England: Pearson Education Limited.

Knerl, L. (2012). Why pay the high price for Apple? Retrieved from http://www.investopedia.com/financial-edge/0312/why-pay-the-high-price-for-apple.aspx.

Kuo, Y. F., Hu, T. L., \& Yang, S. C. (2013). Effects of inertia and satisfaction in female online shoppers on repeat-purchase intention: The moderating roles of word-of-mouth and alternative attraction. Managing Service Quality: An International Journal, 23(3), 168-187. Retrieved from https://doi.org/10.1108/09604521311312219.

Li, G., Li, G., \& Kambele, Z. (2012). Luxury fashion brand consumers in China: Perceived value, fashion lifestyle, and willingness to pay. Journal of Business Research, 65(10), 1516-1522. Retrieved from https://doi:10.1016/j.jbusres.2011.10.019.

McGowan, M., Shiu, E., \& Hassan, L. M. (2016). The influence of social identity on value perceptions and intention. Journal of Consumer Behaviour, an International Review, 16(3), Retrieved from https://doi.org/10.1002/cb.1627.

Nandan, S. (2005). An exploration of the brand identity-brand image linkage: A communications perspective. Journal of Brand Management, 12(3), 264-278. Retrieved from https://doi.org/10.1057/palgrave.bm.2540222.

Ness, E. A., \& Rooney, B. J. (2013). Methods in psychological research, $3^{\text {rd }}$ ed. New York: Sage.

Nielson, S. (2014, February 7). Apple's premium pricing strategy and product differentiation. Yahoo! Tech. Retrieved from https://www.yahoo.com/tech/apple-premium-pricing-strategy-product191247308.html.

Prajapati, V. (2020). 10 reasons why do people buy apple products. Retrieved from https://www.techprevue.com/people-buy-apple-products/.

Razak, N., Themba, O. S., \& Sjahruddin, H. (2019). Brand awareness as predictors of repurchase intention: Brand attitude as a moderator. Advances in Social Sciences Research Journal, 6(2), 541554. Retrieved from https://doi.org/10.14738/assrj.62.6264.

Roberts, K. (2004). Lovemarks: The future beyond brands. New York: Powerhouse Books.

Schultz, D. E. (2005). The lovaltv paradox: What is brand lovaltv after all? Marketing Management. 14(5), 10-11. Retrieved from https://www.scopus.com/record/display.uri?eid=2-s2.0$26644456694 \&$ origin $=$ inward \& $\mathrm{txGid}=5317 \mathrm{a} 3 \mathrm{fa} 2484 \mathrm{a} 00 \mathrm{f} 25 \mathrm{a} 0 \mathrm{ff} 3 \mathrm{fa} 69 \mathrm{~d} 2 \mathrm{e} 47$.

Sebayang, R. (2018, November 6). Penjualan iPhone mengecewakan, saham Apple kena downgrade. CNBN Indonesia. Diakses dari https://www.cnbcindonesia.com/market/20181106111300-1740771/penjualan-iphone-mengecewakan-saham-apple-kena-downgrade.

Thomson, M., Deborah, J. M., \& Park, C. W. (2005). The ties that bind: Measuring the strength of consumers' emotional attachments to brands. Journal of Consumer Psychology, 15(1), 77-79. Retrieved from https://doi.org/10.1207/s15327663jcp1501_10.

Wijaya, B. S. (2013). Dimensions of brand image: A conceptual review from the perspective of brand communication. European Journal of Business and Management, 5(31), 55-65. doi: 10.13140/ejbm.2013.66.65.

Yin-Tsuo, H., Kuo-Wei, L. \& Wen-Yuan, C. (2011). An empirical study of consumer's repurchase intention of tablet PC. The 6th International Conference on Computer Science \& Education. doi: 10.1109/ICCSE.2011.6028609.

Zeithaml, V. A. (2000). Service quality, profitability, and the economic worth of customers: What we know and what we need to learn. Journal of the Academy of Marketing Science, 28(1), 67-85. Retrieved from https://doi.org/10.1177/0092070300281007. 
Jurnal Manajemen Maranatha = Vol. 20 Nomor 1, November (2020) 